\title{
Preparation of nanomaterials from strategic placer heavy minerals recovered from red sediments of badlands topography along the southeast coast of India
}

\author{
Bignaraj Mishra ${ }^{1}$, Satya Sai Srikant ${ }^{2, *}$, Sunita Routray ${ }^{3}$, Tumula Laxmi ${ }^{4}$ and \\ Raghupatruni Bhima Rao ${ }^{5}$ \\ ${ }^{1}$ Indian Rare Earths Limited, Chatrapur 760 002, India \\ ${ }^{2}$ SRM Institute of Science and Technology, Modinagar 201 204, India \\ ${ }^{3}$ C.V. Raman College of Engineering, Bhubaneswar 752 054, India \\ ${ }^{4}$ The Techno School, Bhubaneswar 751 019, India \\ ${ }^{5}$ CSIR-Institute of Minerals and Materials Technology, Bhubaneswar 751 013, India
}

This article deals with heavy placer mine to metals and materials, especially preparation of nanomaterials from strategic minerals of placer deposits which are derived from the badlands topography existing along the east coast of India. In the present study, red sediment samples were collected from the badlands and subjected to physical separation processes to recover high-grade individual placer heavy minerals for valueaddition, which includes preparation of titanium oxide, titania slag, titanium oxide nanomaterials from comminuated ilmenite mineral as well as preparation of zircon flour, and zirconia nanomaterials from natural zircon mineral.

Keywords: Badlands topography, beneficiation, heavy minerals, leaching, nanomaterials.

BADLANDS topography exists all along the coast line in the Eastern part of India. These badlands are recent deposits according to geological timescale. The topography of badlands depends on the geological locations. However, all the badlands release red sediments along with fluvial placer minerals during rainy season. The placer minerals which consist of ilmenite, sillimanite, zircon, monazite, rutile, etc. occur along the fluvial deposits with varying mineral composition and size range $e^{1,2}$. The recovery processes for individual minerals from these badlands vary based on the limitations of ferrous coating, particle size range and presence of garnet. The Atomic Minerals Division, Department of Atomic Energy has done detailed exploration work and characterization of mineral deposits of badlands. CSIR, Institute of Minerals and Materials Technology (IMMT), Bhubaneswar has developed the process flow sheet to recover individual heavy minerals and value-addition of minerals, especially for

*For correspondence. (e-mail: satya.srikant@gmail.com) ilmenite, zircon and sillimanite, which includes preparation of titanium oxide, titania slag, titanium oxide nanomaterials from comminuated ilmenite mineral as well as zircon flour and zirconia nanomaterials from natural size zircon mineral.

Since the advent of nanotechnology, titanium dioxide nanomaterials have been at the centre of research owing to their low cost and simple production process. Thus, titanium dioxide nanoparticles are witnessing high demand; companies offering such solutions can capitalize on the emerging demand trends. The global titanium dioxide nanomaterials market can be divided on the basis of applications like personal-care products, paints and coatings, energy, paper and ink manufacturing, catalysts, and others, including in advanced water filters ${ }^{3,4}$. Another opportunity that companies can capitalize upon is the increasing use of titanium dioxide-based coatings in photovoltaic modules so as to improve their operational efficiency. With the photovoltaic and solar energy market demonstrating exceptional growth rates $^{5}$, the demand for titanium dioxide in this application will be high. Hence, manufacturers are investing heavily in $R \& D$, with several new applications in their pilot or development phases.

Zirconium oxide nanoparticles $\left(\mathrm{ZrO}_{2}\right)$ are available in the form of nanodots, nanofluids and nanoacrystals having a wide surface area. They are often doped with either yttrium oxide, calcia or magnesia to stabilize in high-temperature crystalline phase, such as tetragonal or cubic phase ${ }^{6}$. The zirconium oxide nanoparticles are used in ceramics for making ceramic pigments, porcelain glaze, etc., in artificial jewellery and for making abrasive, insulating and fire-retarding materials; the powder displays pyro-optical properties and hence can be used for optical storage, light shutters and stereo television glasses $^{7-9}$.

The present study deals with the typical badlands along the southeast coast of India. The placer minerals released 


\section{RESEARCH ARTICLES}

from these badlands consist of ilmenite, sillimanite, zircon, traces of monazite and are free from garnet. Researchers from CSIR-IMMT have studied these typical badlands, for recovery of individual placer heavy minerals and their value-addition especially for nanomaterials ${ }^{10}$. The results obtained from mines to nanomaterials are suitable for industrialization.

\section{Materials and methods}

\section{Raw materials}

Red sediment samples were collected from typical badlands topography at three locations along the south east coast of India - Bhimunipatnam, Visakhapatnam district, Andhra Pradesh (AP); Vastavalasa, Srikakulam district, AP (found $6 \mathrm{~m}$ below the beach sand deposit); Basanputti, Ganjam district, Odisha ${ }^{2,10}$. Initially, the red sediment samples of all the three locations were deslimed and subjected to size analysis and sink float studies. The heavy minerals obtained from bromoform sinks were also subjected to magnetic separation using permanent drum magnetic separator at magnetic intensity of $1.2 \mathrm{~T}$. Mineralogical modal analyses of all these three samples were carried out using binocular microscope.

\section{Recovery of heavy minerals}

Recovery of total heavy minerals was carried out for 100 tonnes of sample using desliming units and gravity spirals. Recovery of ilmenite minerals was carried out from the recovery of total heavy minerals. The total heavy minerals were subjected to magnetic separation using a wet high-intensity magnetic separator. The magnetic minerals were further subjected to separation using a high-tension roller separator for the recovery of ilmenite minerals. Zircon minerals were recovered from total non-magnetic minerals via stage high tension separator.

\section{Value-addition}

Initially, the recovered ilmenite sample was subjected to the process of roasting followed by leaching for the preparation of synthetic rutile. Ilmenite sample was also ground to different sizes and subjected to the above leaching processes. Further pre-oxidized ilmenite mineral concentrate was subjected to microwave heating furnace to produce titania slag and iron metal. Finally, nanomaterials were prepared from ilmenite concentrate using sulphuric acid ${ }^{11}$. Figure 1 shows the experimental plan for preparation of nanotitania nanomaterial.

Zircon (as mined) obtained after mineral separation was fused with caustic flakes at $600-650^{\circ} \mathrm{C}$ and leached with water to separate silica as soluble sodium silicate for the preparation of nanomaterials ${ }^{12}$. Required doping was done using a suitable stabilizing oxide at mixing stage to get stabilized zirconium oxide either in cubic or tetragonal form $^{13}$. Figure 2 shows the experimental plan for preparation of zirconium oxide nanomaterial.

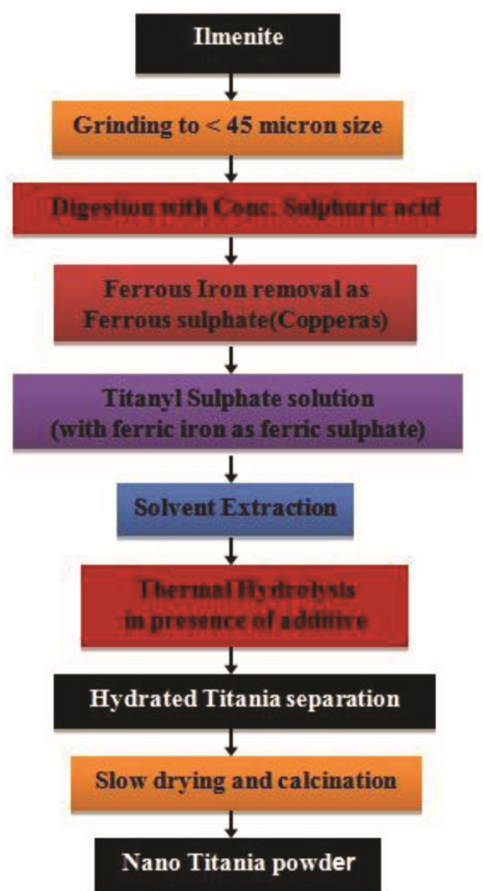

Figure 1. Preparation of nanotitania material.

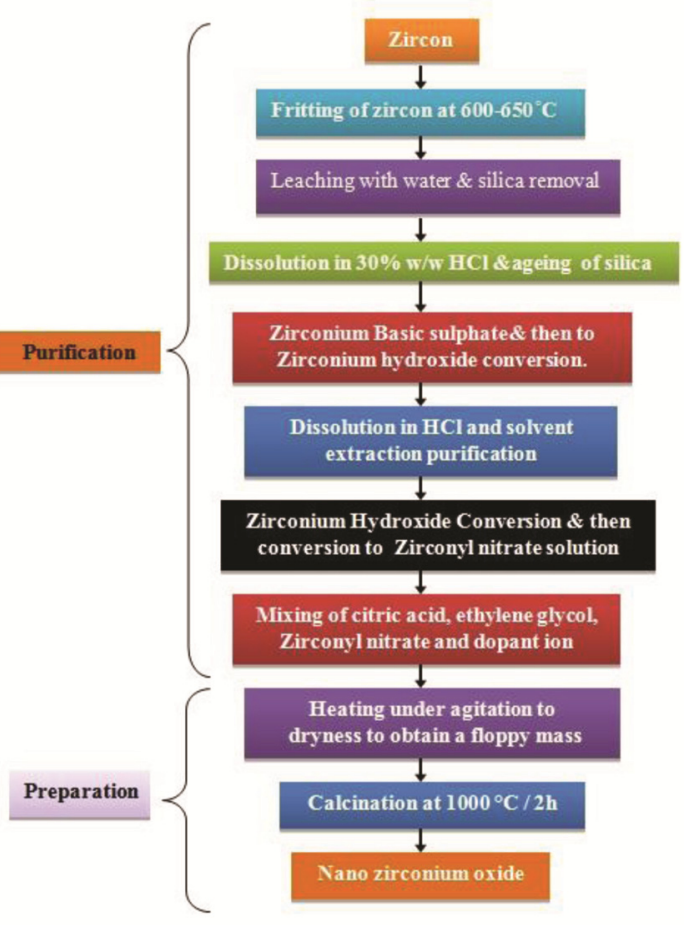

Figure 2. Preparation of nanozirconium oxide. 

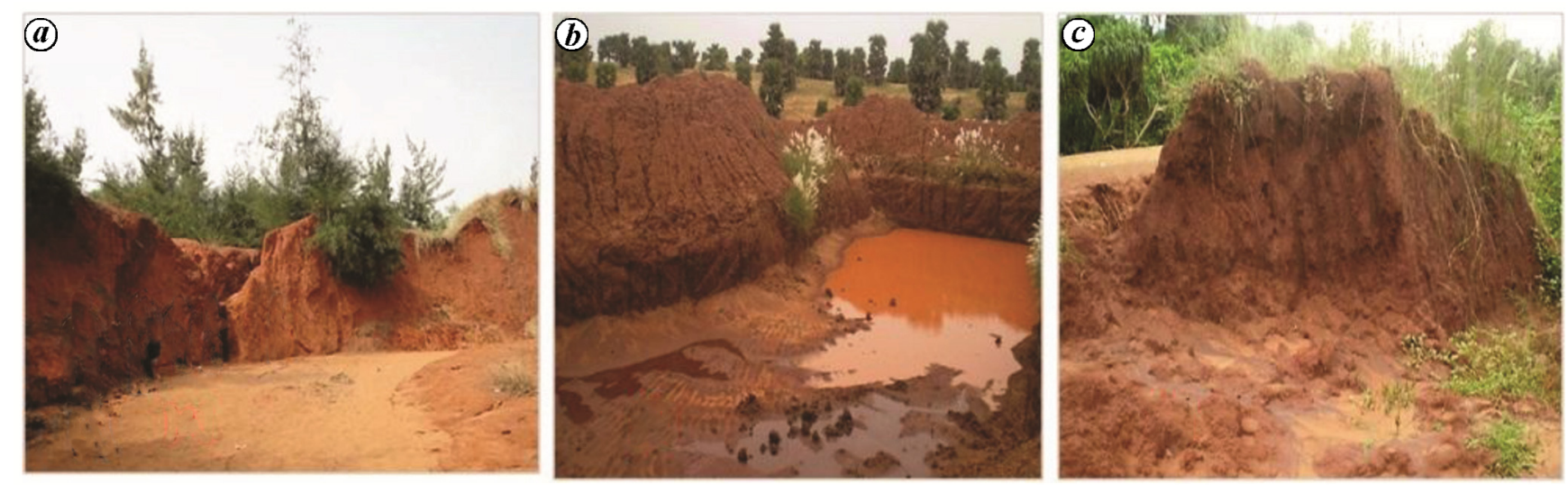

Figure 3. Typical badlands Topography along the southeast coast India. $\boldsymbol{a}$, Bhimunipatnam, Visakhapatnam district; $\boldsymbol{b}$, Vastavalasa, Srikakulam district (found $6 \mathrm{~m}$ below of the beach sand deposit); $\boldsymbol{c}$, Basanputti, Ganjam District, Odisha.
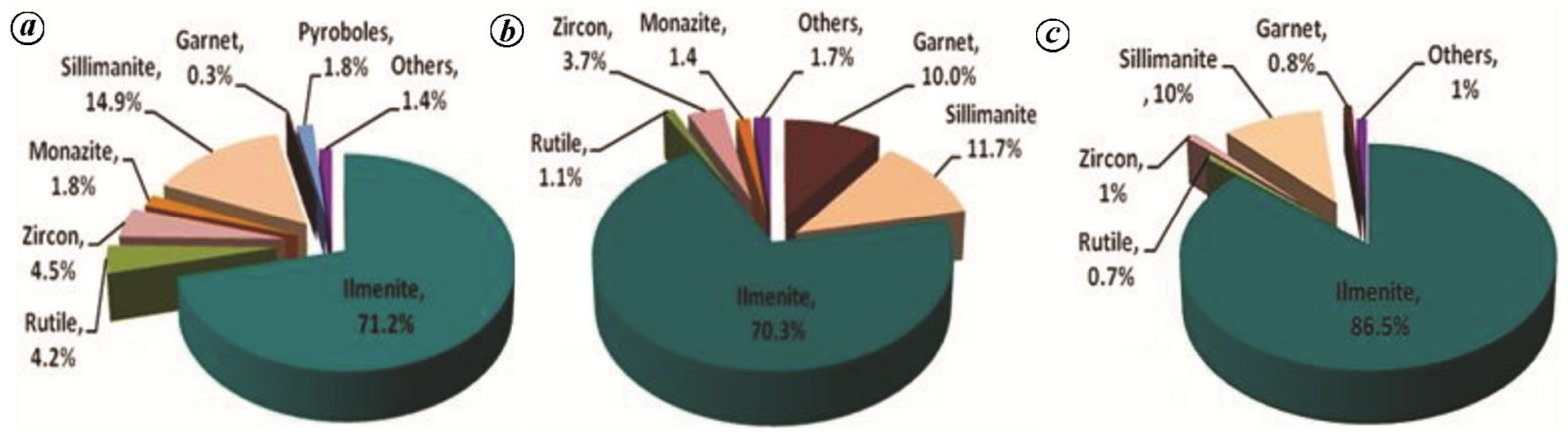

Figure 4. Modal analysis of heavy minerals present in red sediments of badlands topography. $\boldsymbol{a}$, Bhimunipatnam; $\boldsymbol{b}$, Vastavalasa; $\boldsymbol{c}$, Basanputti ${ }^{14,15}$.

\section{Results and discussion}

\section{Modal and size analysis of red sediment samples}

Figure $3 a-c$ shows typical badlands topography along the southeast coast of India. It can be seen from the figure that geo-morphological formations of badlands located in different places depend on the climatic conditions and geological settings as well as geological timescale.

Figure 4 shows mineralogical modal analysis of red sediment samples collected from all three locations. The data indicate strategic minerals present in each deposit: Bhimunipatnam contains ilmenite $71.2 \%$ and zircon $4.5 \%$ by weight; Vastavalasa contains ilmenite $70.3 \%$ and zircon $3.7 \%$ by weight; Basanputti, contains ilmenite $86.5 \%$ and zircon $1 \%$ by weight.

Figures 5-7 show the deslimed feed size analysis as well as total heavy minerals, total very heavy minerals, total light heavy minerals, total magnetic heavy minerals and total non-magnetic heavy minerals size analysis of red sediment samples in all three locations ${ }^{14,15}$. The data indicate that there is a distinct difference in size analysis of all three deposits, but with reference to the mineral processing equipment such as hydro-cyclones for deslim- ing, gravity spirals, gravity tables, magnetic and electrostatic separator used for separation of individual minerals, the difference in size range in all three deposits is the same.

It is clear from Figures 4-7 that the Odisha coastal belt red sediments of badlands topography contain more ilmenite $(86.5 \%$ by weight). Hence with regard to ilmenite content as well as transport of 100 tonnes of sample for processing, the Odisha coastal belt red sediment fluvial deposit sample (contains 33.2\% THM (total heavy minerals)) was chosen for mineral separation followed by recovery of ilmenite and zircon for value-addition studies. The bulk sample was subjected to desliming to recover total sand. The sand was subjected to seven stage spirals to recover total heavy minerals (Figure 8$)^{15}$.

The data indicate that total heavy mineral concentrate contains $99.1 \%$ grade of THM, with $97.9 \%$ recovery from the feed sample containing $33.2 \%$ THM.

\section{Recovery of strategic minerals}

The recovered total heavy minerals (Figure 8), were subjected to separation using a wet high-intensity magnetic separator to recover total magnetic minerals including 

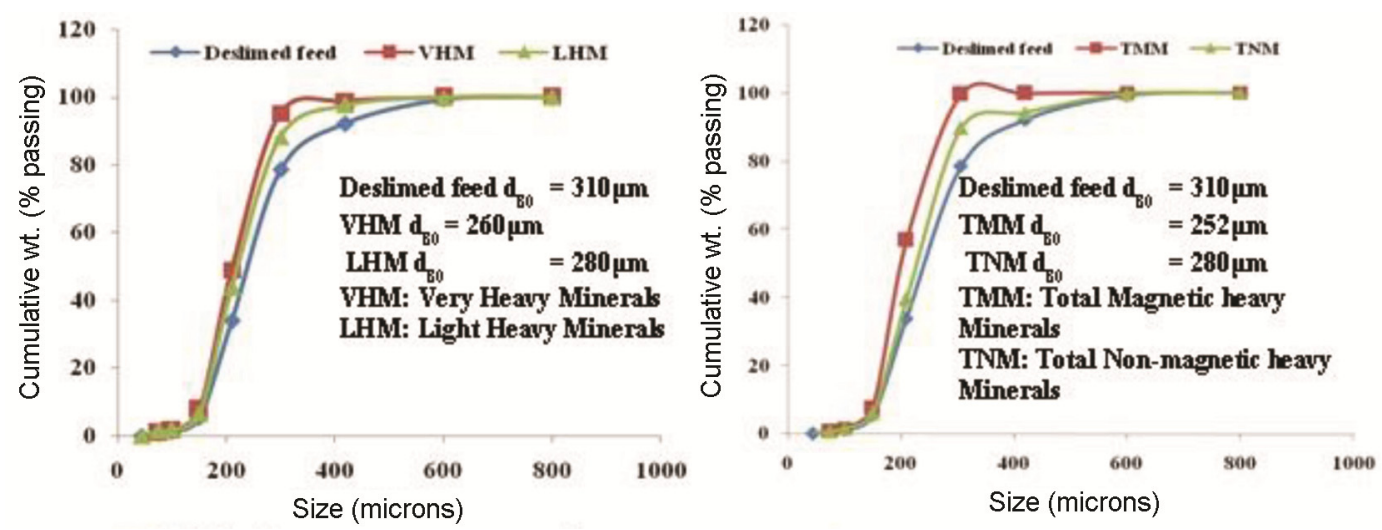

Figure 5. Size analysis of deslimed feed, very heavy minerals (VHM), light heavy minerals (LHM), total magnetic minerals (TMM) and total nonmagnetic minerals (TNM) of red sediments of Bhimunipatnam.
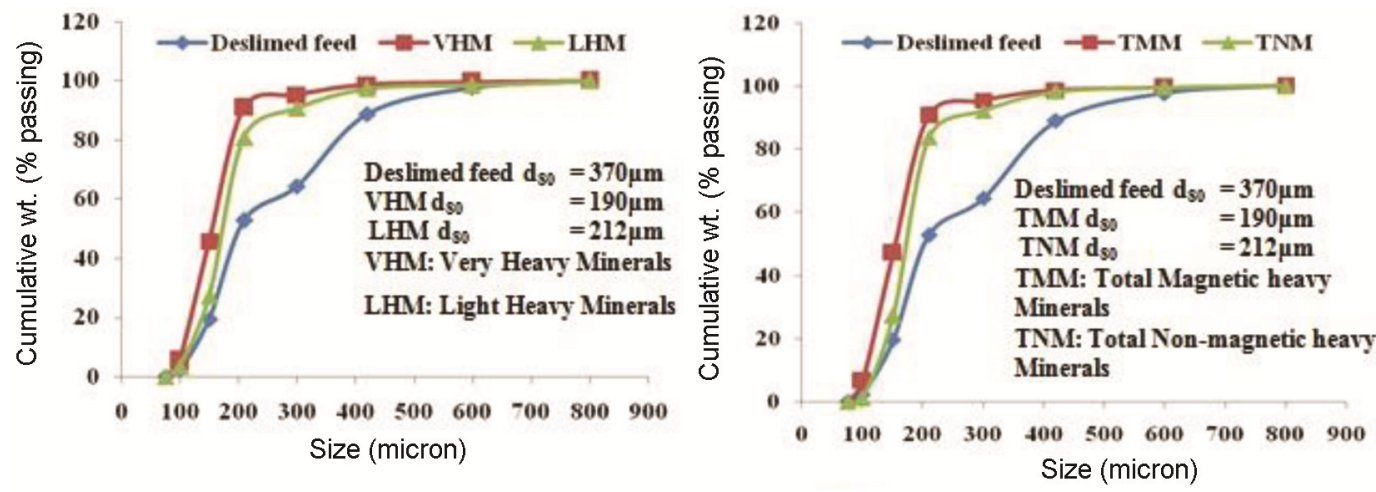

Figure 6. Size analysis of deslimed feed, VHM, LHM, TMM and TNM of red sediments of Vastavalasa.
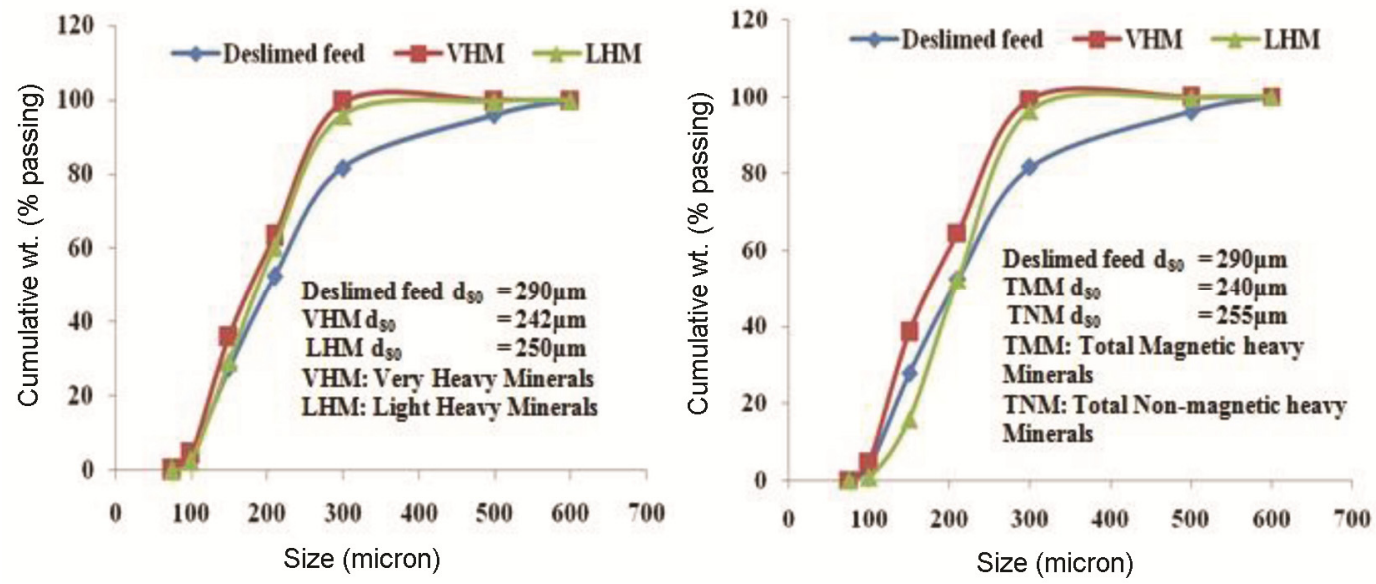

Figure 7. Size analysis of deslimed feed, VHM, LHM, TMM and TNM of red sediments of Basanputti.

ilmenite, monazite and traces of garnet and pyribole minerals. These total magnetic minerals were separated using high tension separator for recovery of conducting minerals ilmenite (Figure 9). The data indicate that the ilmenite grade having $99.7 \%$ is recovered with $89 \%$ recovery from a deslimed feed (i.e. with $48.5 \%$ ilmenite). The non-magnetic minerals obtained from ilmenite
(Figure 9) were separated using gravity tables to recover heavy minerals.

The deslimed recovered heavy minerals were subjected to two-stage flotation to remove sillimanite mineral and obtain other mineral concentrates which contain mostly zircon and rutile (in the tailings). The flotation tailings were separated using a two-stage high-tension roller 
RESEARCH ARTICLES

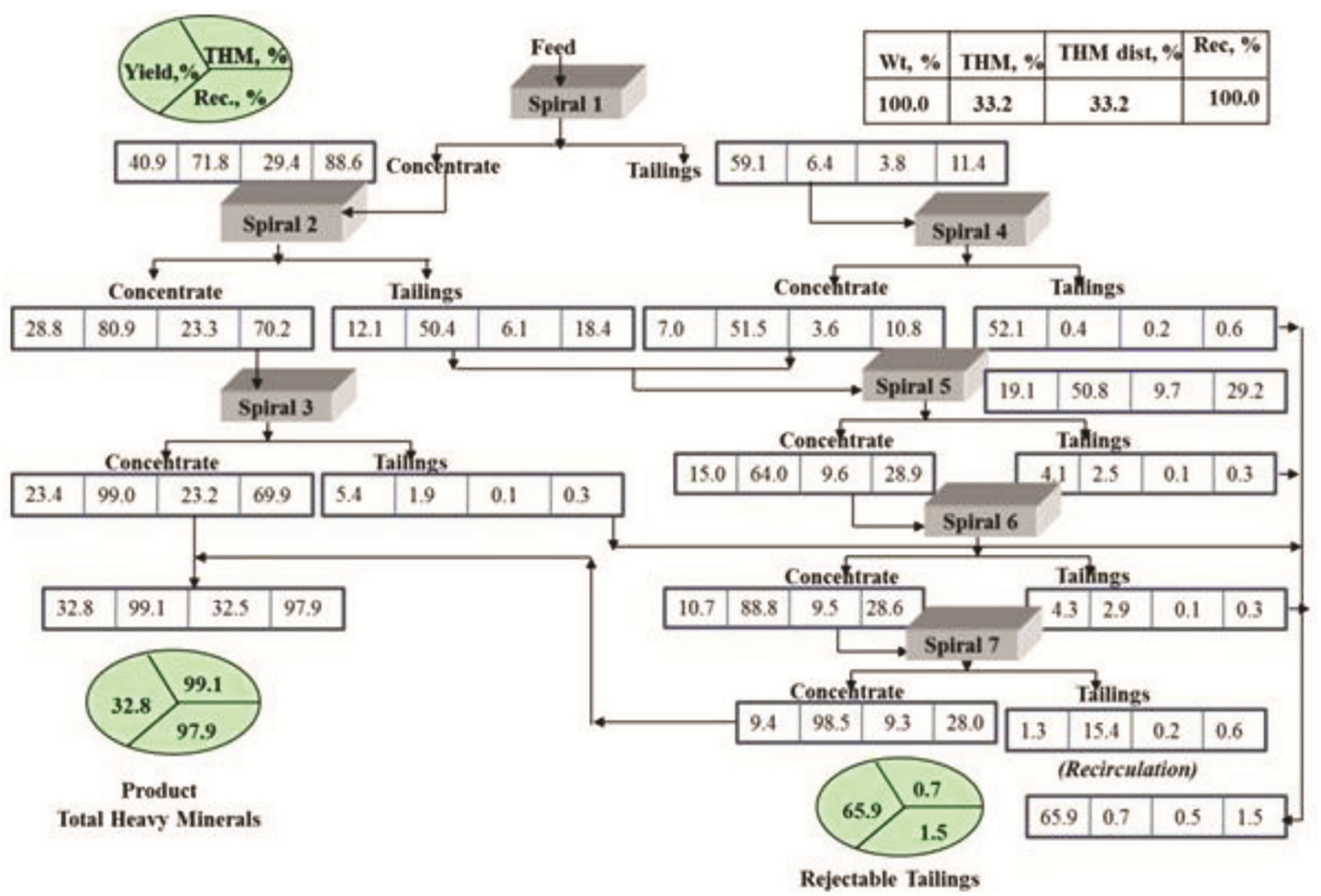

Figure 8. Flow sheet with material balance on recovery of total heavy minerals from red sediments of Basanputti village using seven-stage spirals.

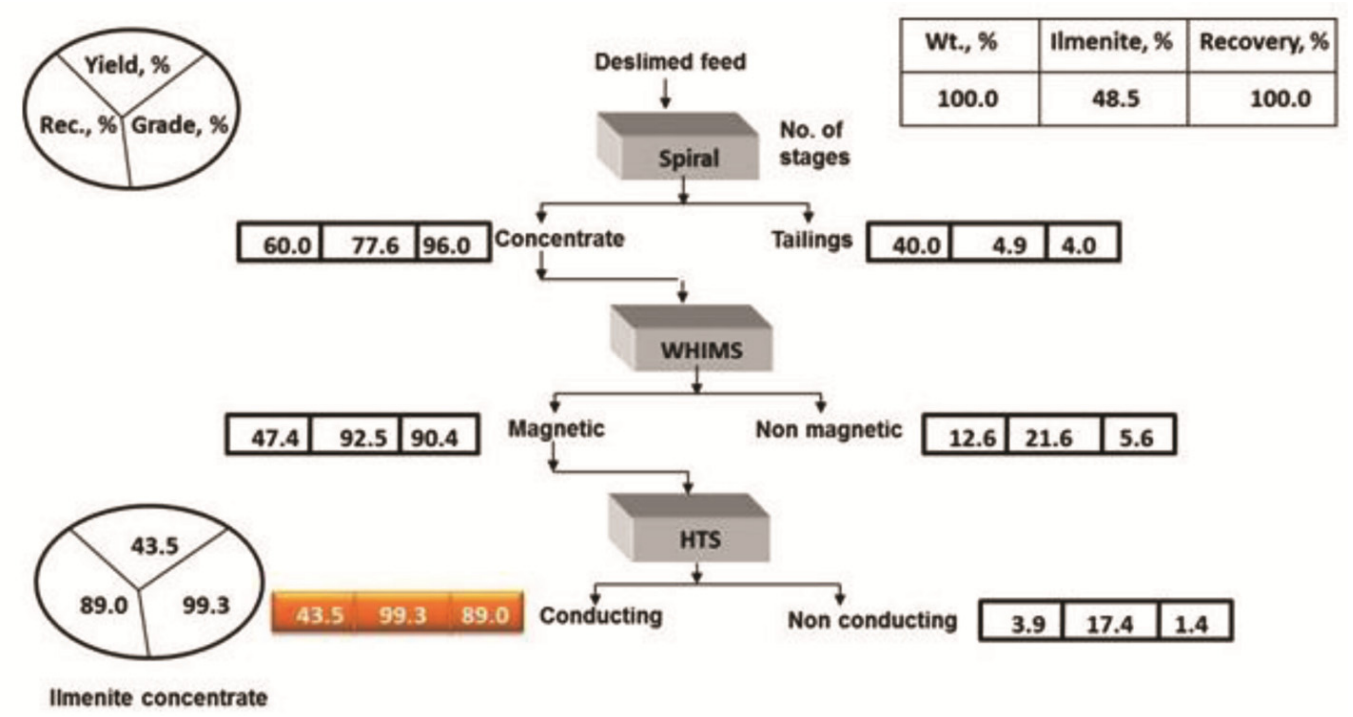

Figure 9. Flow sheet with material balance on recovery of ilmenite from deslimed red sediment sample along Odisha coast.

separator to recover non-conducting zircon mineral concentrate (Figure 10).

The data indicate that zircon concentrate obtained by this physical separation processes contains $98.1 \%$ zircon mineral concentrate, with $80 \%$ recovery from a feed sample (i.e.
$3.8 \%$ zircon mineral). Tables 1 and 2 provide the complete chemical analysis of ilmenite and zircon respectively. The data indicate that ilmenite mineral concentrate contains 49.1\% $\mathrm{TiO}_{2}, 14.98 \% \mathrm{Fe}_{2} \mathrm{O}_{3}$ and $33.18 \% \mathrm{FeO}$. The zircon mineral concentrate contains $63.3 \% \mathrm{ZrO}_{2}$ and $31.3 \% \mathrm{SiO}_{2}$. 


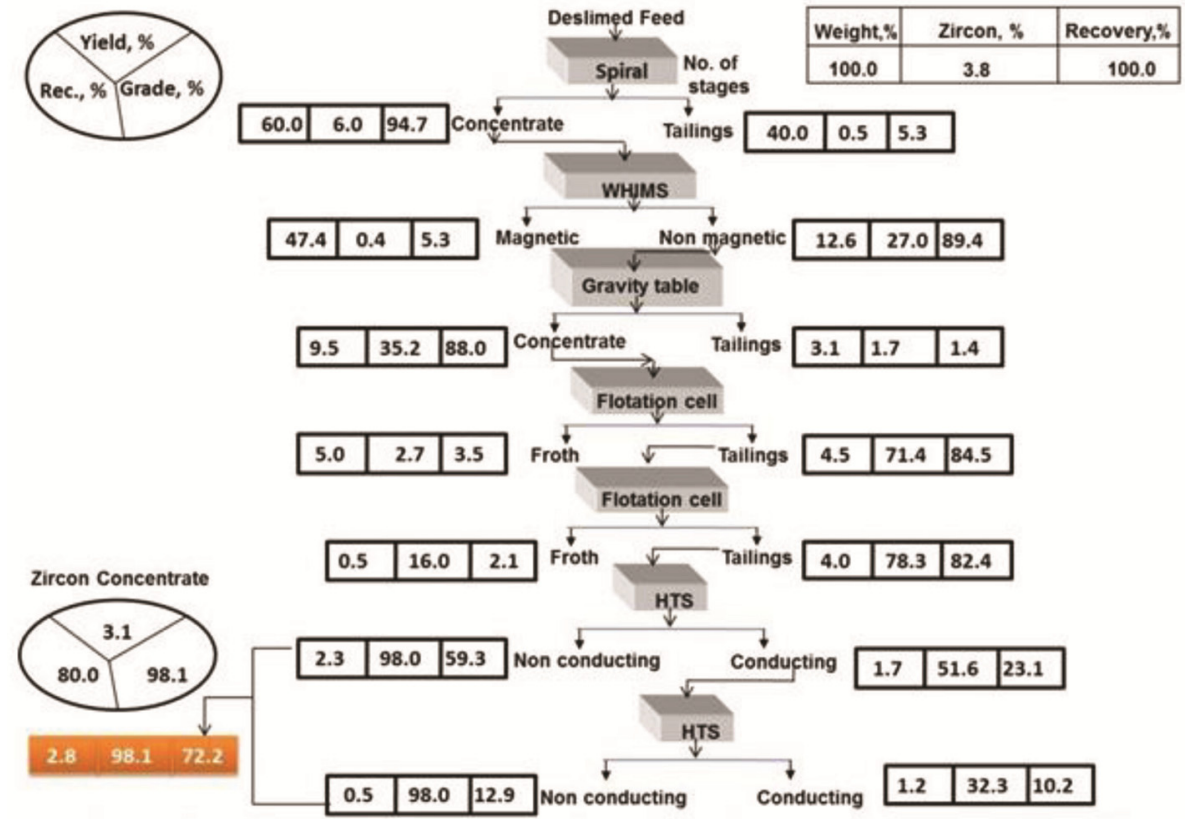

Figure 10. Flow sheet with material balance on recovery of zircon from deslimed red sediment sample along Odisha coast.

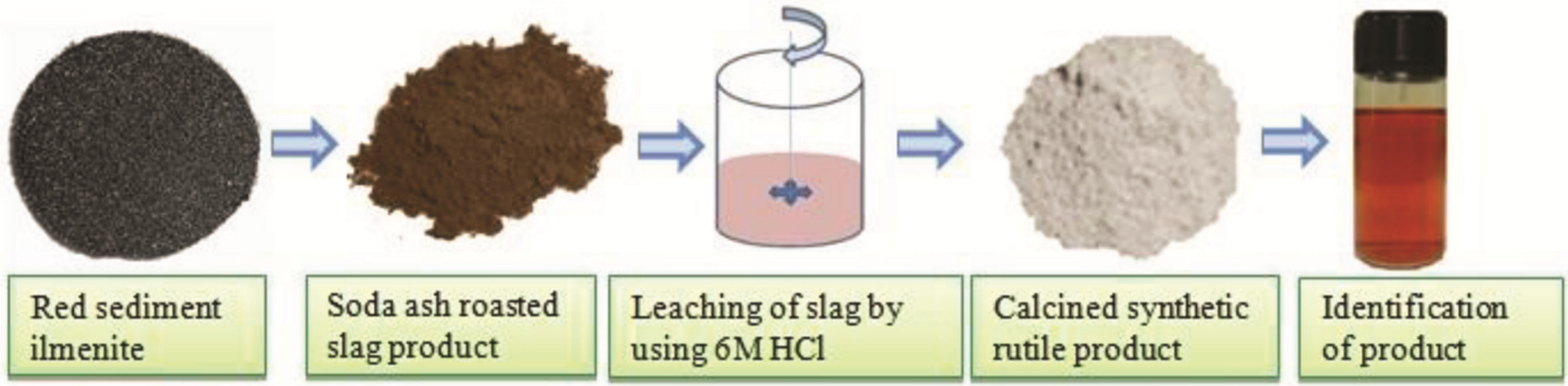

Figure 11. Graphical representation of leaching kinetics of soda ash roasted slag of red sediment ilmenite for production of synthetic rutile ${ }^{15}$.

(a)
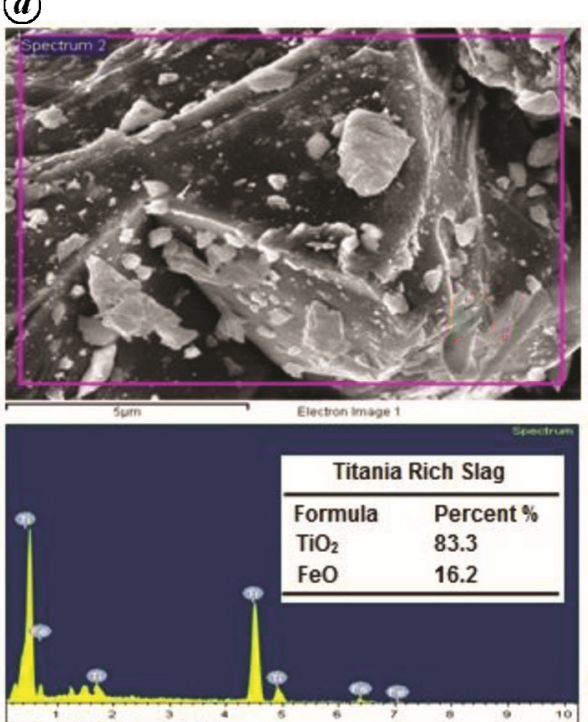

Figure 12. SEM-EDAX data of ilmenite minerals heated in a microwave furnace: $(\boldsymbol{a})$ titania rich slag and $(b)$ metallic iron ${ }^{17}$ (b)
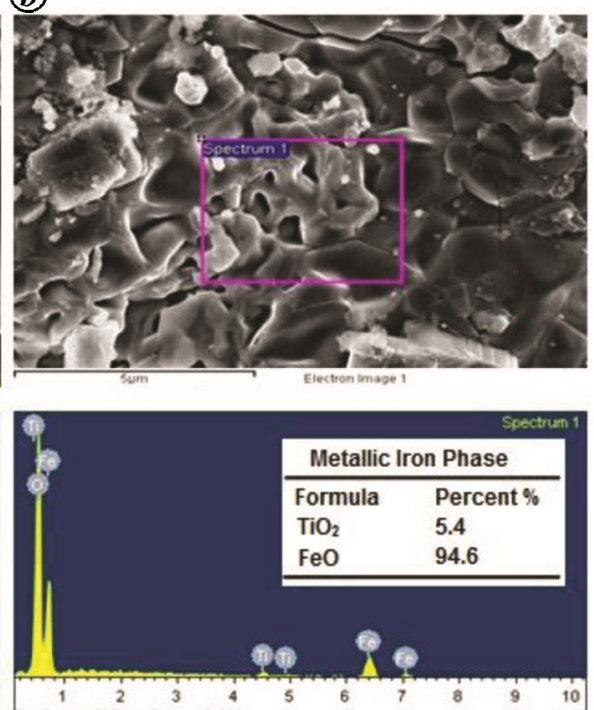

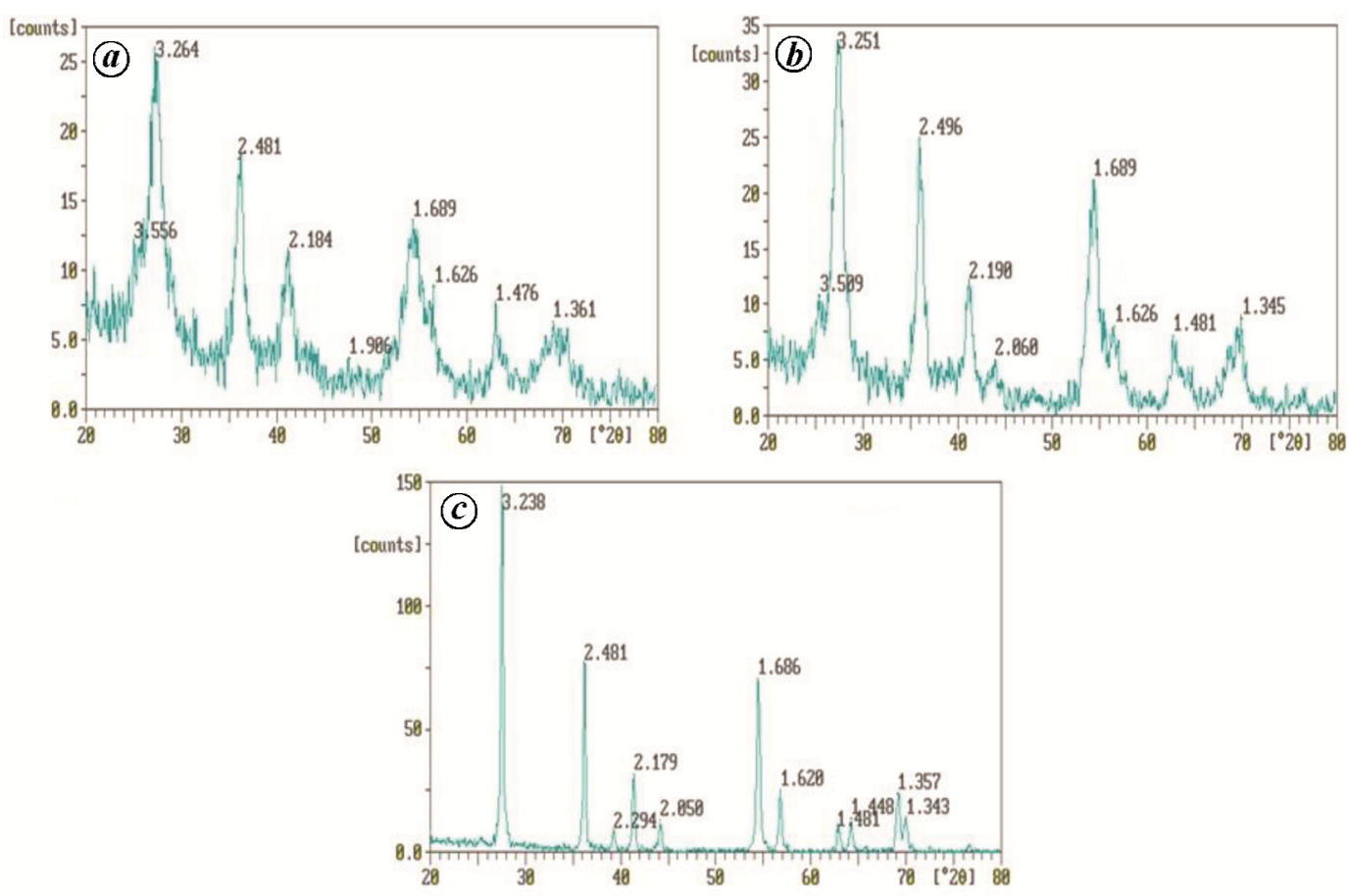

Figure 13. $\mathrm{XRD}$ data for nanotitanium dioxide at different calcination conditions: $\boldsymbol{a}$, $\mathrm{TiO}_{2}$ dried at $110^{\circ} \mathrm{C}$ for $1 \mathrm{~h}$; $\boldsymbol{b}, \mathrm{TiO}_{2}$ calcined at $400^{\circ} \mathrm{C} ; \boldsymbol{c}, \mathrm{TiO}_{2}$ dried at $750^{\circ} \mathrm{C}$ for $2 \mathrm{~h}$.

(a)

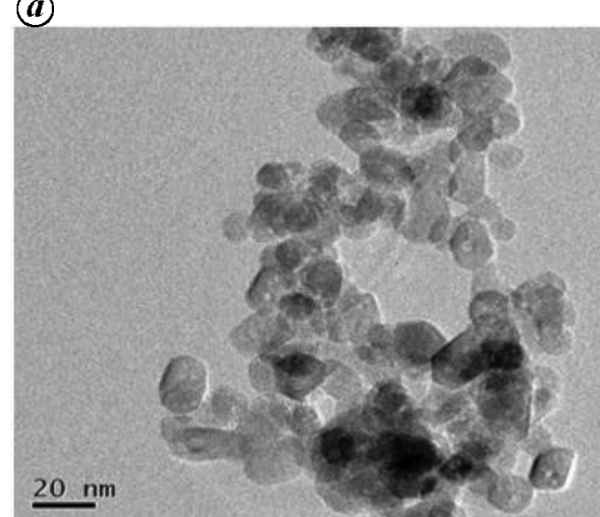

(b)

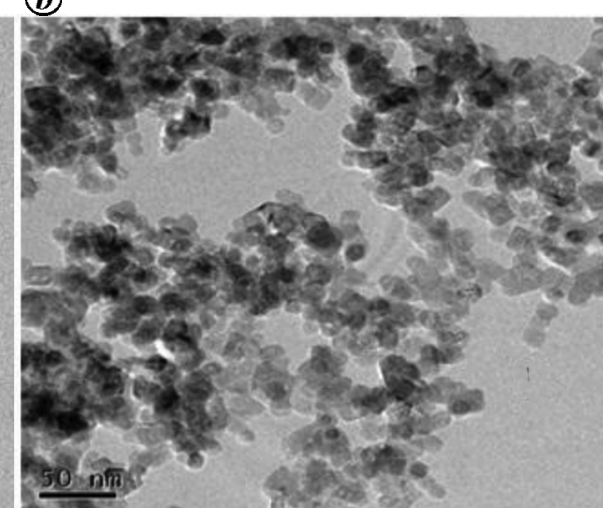

Figure 14. Transmission electron micrograph (TEM) of titania nanoparticles with high resolution of (a) 20 and (b) $50 \mathrm{~nm}$.

Table 1. Complete chemical analysis of ilmenite mineral concentrate ${ }^{14,15}$

\begin{tabular}{lcccccc}
\hline $\mathrm{TiO}_{2}(\%)$ & $\mathrm{FeO}(\%)$ & $\mathrm{Fe}_{2} \mathrm{O}_{3}(\%)$ & $\mathrm{Al}_{2} \mathrm{O}_{3}(\%)$ & $\mathrm{SiO}_{2}(\%)$ & $\mathrm{Th}(\mathrm{ppm})$ & $\mathrm{U}(\mathrm{ppm})$ \\
\hline 49.10 & 33.18 & 14.98 & 0.52 & 0.48 & 35 & $<4$ \\
\hline
\end{tabular}

\section{Value-addition}

Ilmenite: Titanium dioxide was prepared using a chemical process as well as pyrometallurgical route, including conventional muffle furnace and microwave heating furnace. Initially calcined synthetic rutile product was prepared from red sediment ilmenite by generating soda ash roasted slag product which was subsequently leached using $6 \mathrm{M} \mathrm{HCl}$. Figure 11 shows a graphical representation of the process from which white calcined synthetic rutile product is obtained.

Table 3 provides the complete chemical analysis of calcined synthetic rutile product. The data indicate that calcined synthetic rutile product contains $97.21 \% \mathrm{TiO}_{2}$, $1.68 \% \mathrm{Fe}_{2} \mathrm{O}_{3}$ and traces of $\mathrm{Al}_{2} \mathrm{O}_{3}$ and $\mathrm{SiO}_{2}$. This product is suitable for industrial applications. 


\begin{tabular}{|c|c|c|c|c|c|c|}
\hline $\mathrm{ZrO}_{2}(\%)$ & $\mathrm{SiO}_{2}(\%)$ & $\mathrm{HfO}_{2}(\%)$ & $\mathrm{Al}_{2} \mathrm{O}_{3}(\%)$ & $\mathrm{TiO}_{2}(\%)$ & $\mathrm{FeO}(\%)$ & $\mathrm{Fe}_{2} \mathrm{O}_{3}(\%)$ \\
\hline 62.70 & 29.7 & 0.9 & 4.3 & 0.1 & 0.4 & 0.8 \\
\hline
\end{tabular}

Table 3. Complete chemical analysis of calcined synthetic rutile product ${ }^{15}$

\begin{tabular}{cccc}
\hline $\mathrm{TiO}_{2}(\%)$ & $\mathrm{Fe}_{2} \mathrm{O}_{3}(\%)$ & $\mathrm{Al}_{2} \mathrm{O}_{3}(\%)$ & $\mathrm{SiO}_{2}(\%)$ \\
\hline 97.21 & 1.68 & 0.31 & 0.27 \\
\hline
\end{tabular}

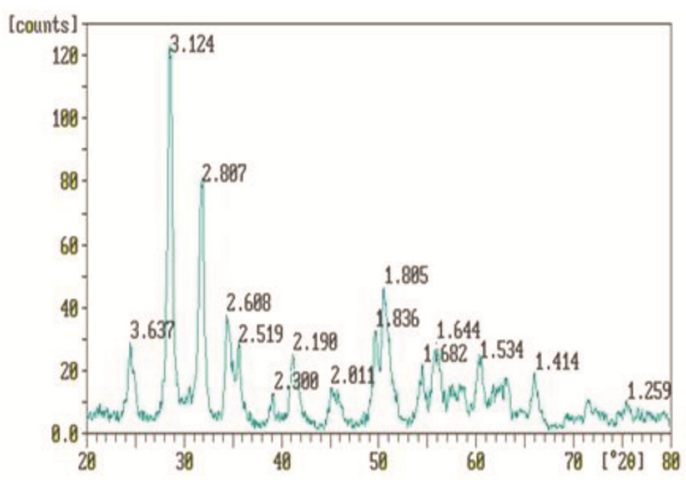

Figure 15. X-ray diffraction (XRD) patterns for zirconium oxide nanoparticles.
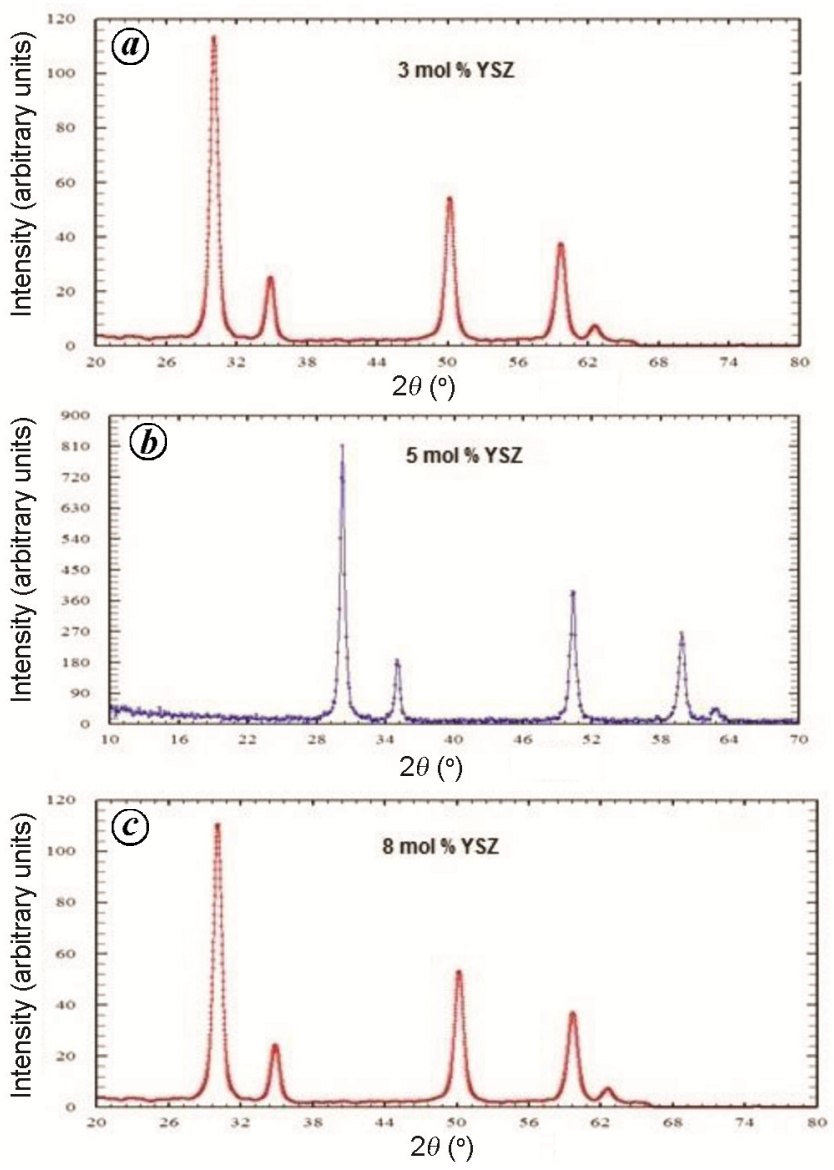

Figure 16. XRD patterns of yttria-doped zirconium oxide (YSZ) for (a) 3, (b) 5 and (c) $8 \mathrm{~mol} \%$.
Similarly, the red sediment ilmenite sample was subjected to reduction roasting followed by metallization (process) in a microwave heating furnace. In the conventional furnace, it takes more than $3 \mathrm{~h}$ at $1200^{\circ} \mathrm{C}$, whereas in the microwave heating furnace, it takes only $45 \mathrm{~min}$ at lower than $1000^{\circ} \mathrm{C}$. The product obtained was analysed using SEM-EDAX for the identification of titania slag and iron metal (Figure 12). Titania-rich slag (Figure $12 a$ ) contains $\mathrm{TiO}_{2} \quad 83.3 \%$ and $\mathrm{FeO} 16.2 \%$ by weight. Similarly, the metallic iron phase shows $\mathrm{TiO}_{2} 5.4 \%$ and $\mathrm{FeO}$ $94.6 \%$ by weight (Figure $12 b$ ).

Formation of nanotitania particles: Table 4 gives the composition of the dissolution liquor obtained from $500 \mathrm{~kg}$ batch after two stages of leaching from red sediment ilmenite. The data indicate that the liquor contains $94.3 \mathrm{gpl} \mathrm{TiO}_{2}$. The hydrated titania was subjected to characterization using thermal analyser (TG-DTA), X-ray diffraction (XRD) analysis, surface area with BrunauerEmmett-Teller (BET) calculation and transmission electron microscopy (TEM) analysis. The results of TG-DTA analysis showed that weight loss of hydrated titania took place up to $400^{\circ} \mathrm{C}$. Maximum weight loss was found to be $97 \%$ at this temperature. XRD data for dried as well as for sample calcined at $400^{\circ} \mathrm{C}$ showed that hydrated titania was in anatase phase. The crystallite size $(X)$ was calculated using Scherrer's formula and surface area $(Y)$ of the samples was analysed by nitrogen adsorption principle using BET. Table 5 shows the results. The table also shows results of particle size $(Z)$ for titania samples from TEM analysis.

Table 6 shows results of crystalline size analysis with TEM after addition of sodium dodecyl sulphate (SDS). The synthesis of nanorutile at low temperature has been carried out using SDS solution. Figure 13 shows the XRD data for nanorutile, while Figure 14 shows results of TEM analysis of titania nanoparticles with high resolution of 20 and $50 \mathrm{~nm}$.

Zircon: Zircon mineral concentrate obtained from sediment sample (heavy mineral concentrate contains $1 \%-4 \%$ by weight) was ground using ball mill, agitated mill and dual planetary ball mill ${ }^{16,17}$ to obtain particle below $45 \mu \mathrm{m}$ for the preparation of nanomaterials. It was observed from the grindability characteristics of zircon that it is difficult to get finer size; moreover, the process is energy-intensive. The data indicate that around $6-8 \mathrm{~h}$ is required to grind zircon to below $45 \mu \mathrm{m}$ using dual planetary ball mill. Hence natural zircon mineral obtained from red sediment was used for preparation of nanozircon. 
Table 4. Composition of the dissolution liquor (for two-stage leaching process with $96 \%$ recovery)

\begin{tabular}{|c|c|c|c|c|c|}
\hline $\begin{array}{l}\mathrm{TiO}_{2} \\
(\mathrm{gpl})\end{array}$ & $\begin{array}{l}\text { Total Fe } \\
\quad(\mathrm{gpl})\end{array}$ & $\begin{array}{c}\mathrm{FeSO}_{4} \\
(\mathrm{gpl})\end{array}$ & $\begin{array}{l}\mathrm{Fe}_{2}\left(\mathrm{SO}_{4}\right)_{3} \\
\quad(\mathrm{gpl})\end{array}$ & $\begin{array}{l}\text { Solid content } \\
\text { unreacted ilmenite }(\mathrm{kg})\end{array}$ & $\begin{array}{l}\text { Weight of } \mathrm{TiO}_{2} \\
(\mathrm{~kg})\end{array}$ \\
\hline 94.3 & 64.0 & 139 & 48.2 & 40 & 10 \\
\hline
\end{tabular}

Table 5. Crystallite size data, surface area and particle size data

\begin{tabular}{lccc}
\hline Sample & $\begin{array}{c}\text { Crystallite size }(X) \\
\text { (with XRD data) }\end{array}$ & $\begin{array}{c}\text { Surface area }(Y) \\
\text { (with BET data) }\end{array}$ & $\begin{array}{c}\text { Particle size }(Z) \\
\text { (with TEM data) }\end{array}$ \\
\hline $\begin{array}{l}\text { Dried at } 110^{\circ} \mathrm{C} \\
\text { Calcined at } 400^{\circ} \mathrm{C}\end{array}$ & $4.2 \mathrm{~nm}$ & $126 \mathrm{~m}^{2} / \mathrm{g}$ & $20 \mathrm{~nm}$ \\
\hline
\end{tabular}

Table 6. TEM analysis after addition of sodium dodecyl sulphate (SDS) solution

\begin{tabular}{lccc}
\hline Sample $(\mathrm{nm})$ & $\begin{array}{c}\text { Dried } \\
\text { at } 110^{\circ} \mathrm{C}\end{array}$ & $\begin{array}{c}\text { Calcined at } \\
400^{\circ} \mathrm{C}\end{array}$ & $\begin{array}{c}\text { Calcined } \\
\text { at } 500^{\circ} \mathrm{C}\end{array}$ \\
\hline Crystalline size & 5.0 & 9.0 & 19.0 \\
\hline
\end{tabular}

Table 7. Summary of the characterization results of zircon nanomaterials

\begin{tabular}{lcc}
\hline Sample & $\begin{array}{c}\text { Average particle size } \\
\text { from TEM }(\mathrm{nm})\end{array}$ & $\begin{array}{c}\text { BET surface area } \\
\left(\mathrm{m}^{2} / \mathrm{g}\right)\end{array}$ \\
\hline Pure zirconia & $\sim 30$ & 20.3 \\
$3 \mathrm{~mol} \%$ YSZ & $\sim 20$ & 20.6 \\
$5 \mathrm{~mol} \%$ YSZ & $\sim 20$ & 23.9 \\
$8 \mathrm{~mol} \%$ YSZ & $<20$ & 24.9 \\
\hline
\end{tabular}

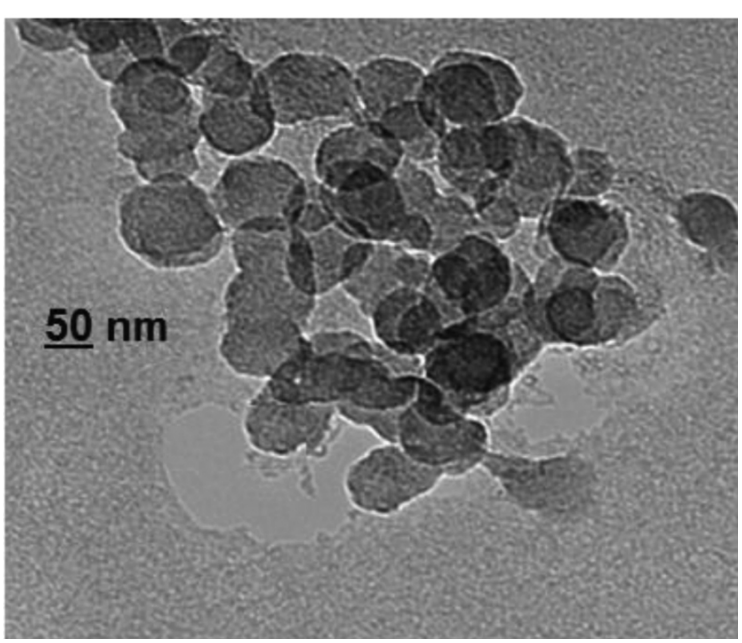

Figure 17. TEM of zirconia nanoparticles

Figure 15 shows the XRD pattern for zirconium oxide nanoparticle, while Figure 16 shows XRD patterns for 3, 5 and $8 \mathrm{~mol} \%$ yttria-doped zirconium oxide. Figure 17 shows results of high-resolution TEM analysis of zirconia nanoparticles. Table 7 provides the summary of the characterization results of zircon nanomaterials.

The existence of nanoparticles was confirmed by measuring particle size using high-resolution TEM, which revealed the nanonature of the powder. The average size of the particles was found to be $\sim 50 \mathrm{~nm}$ (Figure 17). The average specific surface area measured by BET method was found to be in the range $20-24 \mathrm{~m}^{2} / \mathrm{g}$.

\section{Conclusion}

The Indian coast contains a huge amount of heavy placer minerals. The Indian Rare Earths Limited, Government of India, and private companies are in the process of recovering individual minerals. So far, no attempt has been made to recover individual placer nanominerals for valueaddition. This article deals with mines to nanomaterials from badlands topography along the SE coast of India. Following are the findings and outcomes for this study:

(a) The badlands occur throughout the east coast of India. During rainy season, the placer minerals are released and transported by rivers to the sea. These badlands contain $6 \%$ heavy minerals.

(b) Ilmenite contains $60 \%-80 \%$, whereas zircon mineral contains $1-4 \%$ of heavy mineral concentrate.

(c) The study reveals that the heavy placer minerals which consist of ilmenite, sillimanite, zircon, monazite, rutile, etc. recovered from badlands are finer than the beach sand minerals.

(d) The separation processes involved to recover heavy minerals from badlands are different from the beach sand minerals because of lower size range, ferrous surface coating on the minerals and absence of garnet mineral.

(e) The chemical analysis reveals that ilmenite contains $48 \% \mathrm{TiO}_{2}$ and zircon contains $62.7 \% \mathrm{ZrO}_{2}$.

(f) The study reveals that one can obtain titania-rich slag up to $83 \%$ by heating ilmenite minerals in a microwave furnace with less metallization. 


\section{RESEARCH ARTICLES}

(g) The study also reveals that metallization by conventional process took $3 \mathrm{~h}$ at $1200^{\circ} \mathrm{C}$ and with microwave heating furnace, it took $45 \mathrm{~min}$ at below $1000^{\circ} \mathrm{C}$.

(h) The grindability characters of ilmenite indicate that fineness of the mineral increases with time and type of mill, whereas grindability of zircon is found to be difficult.

(i) It is also found that during preparation of nanomaterials, higher surface area of ilmenite gives more favourable conditions, whereas zircon does not. Hence ground ilmenite is used for the preparation of nanomaterials, whereas for zircon, the natural recovered mineral without milling is used for preparation of nanomaterials.

(j) The results reveal that from these resources, one can prepare nanotitanium dioxide and nano zirconium oxide after recovering individual heavy minerals from badlands along the SE coast of India, and these are suitable for industrial applications.

1. Babu, N., Vasumathi, N. and Rao, R. B., Recovery of ilmenite and other heavy minerals from Teri sands (red sands) of Tamil Nadu, India. J. Miner. Mater. Character. Eng., 2009, 8, 149-159.

2. Laxmi, T. and Rao, R. B., Badland topography of coastal belt red sediment deposits of India: a potential resource for industrial minerals. Mines Miner. Rep., 2010, 3, 12-18.

3. Yuan, S., Chen, W. and $\mathrm{Hu}, \mathrm{S}$., Fabrication of $\mathrm{TiO}_{2}$ nanoparticles/ surfactant polymer complex film on glassy carbon electrode. Mater. Sci. Eng., 2005, 25, 479-485.

4. Zhang, L., Zhu, Y., He, Y., Li, W. and Sun, H., Preparation and performances of mesoporous $\mathrm{TiO}_{2}$ film photocatalyst supported on stainless steel. Appl. Catal. B: Environ., 2003, 40, 287-292.

5. Mubarak, A. K., Shauk, M. M. K., Mahir, A. M., Sabia, S., Jahid, M. M. I. and Jasim, U., Sensitization of nanocrystalline titanium dioxide solar cells using natural dyes: influence of acids medium on coating formulation. Am. Acad. Scholar. Res. J., 2012, 4(5), 1-10.

6. Ranjbar, M., Yousefi, M., Lahooti, M. and Malekzadeh, A., Preparation and characterization of tetragonal zirconium oxide nanocrystals from iso-phthalic acid-zirconium (IV) nano-composite as a new precursor. Int. J. Nanosci. Nanotechnol., 2012, 8, 191-196.
7. Behbahani, A., Rowshanzamir, S. and Esmaeilifar, A., Hydrothermal synthesis of zirconia nanoparticles from commercial zirconia. Proc. Eng., 2012, 42, 992-1003.

8. Aysar, S. K., Elias, S., Zakaria, A. and Soltani, N., Structural and optical properties of zirconia nanoparticles by thermal treatment synthesis. J. Nanomater., 2016, Article ID 1913609.

9. Rouge, A. L. et al., Synthesis and nonlinear optical properties of zirconia-protected gold nanoparticles embedded in sol-gel derived silica glass. Mater. Res. Exp., 2015, 2, doi:10.1088/2053-1591/2/ $5 / 055009$

10. Laxmi, T., Nishad, P., Jayadevan, K. E. and Rao, R. B., Textural and concentration pattern of heavy minerals in red sediments of badlands topography Bhimunipatnam, Visakhapatnam Dist., India. J. Min. Metallur., 2011, 47, 75-91.

11. Brian, R. D. and Joseph, A. R., Process for manufacturing titanium dioxide, US patent 4288418A, 1980.

12. Sindlinger, C. J. and Clayton, C. C., Process for preparing alkali metal zirconate from zircon. US patent US2962346A, 1960.

13. Singh, A. K., Pathak, L. C. and Roy, S. K., Effect of citric acid on the synthesis of nano-crystalline yttria stabilized zirconia powders by nitrate-citrate process. Ceram. Int., 2007, 33, 1463-1468.

14. Sunita, R., Development of flowsheet for recovery of individual heavy minerals from SE coast of India with special reference to in-depth characterization of zircon minerals. Ph D thesis, Siksha 'O' Anusandhan University, Bhubaneswar, India, 2011.

15. Laxmi, T., Development of flow sheet for recovery of individual heavy minerals from the badlands topography of SE coast of India and its value addition. $\mathrm{Ph} \mathrm{D}$ thesis, Siksha ' $\mathrm{O}$ ' Anusandhan University, Bhubaneswar, India, 2013.

16. Srikant, S. S., Jayasankar, K., Mukherjee, P. S. and Rao, R. B., Effect of microwave heat treatment on grindability of zircon in a planetary ball mill. AT Int. - Min. Process., 2013, 54, 55-63.

17. Srikant, S. S., Microwave processing of beach placer heavy minerals. Ph D thesis, Siksha 'O' Anusandhan University, Bhubaneswar, India, 2014.

ACKNOWLEDGEMENTS. We thank the Board of Research in Nuclear Sciences (BRNS), Mumbai for support to carry out this study. We also thank the research students; Director, CSIR-Institute of Minerals and Materials Technology, Bhubaneswar and Chief Managing Director, Indian Rare Earths Limited, Chatrapur for providing the necessary facilities to carry out this work.

Received 30 August 2018; revised accepted 28 January 2019

doi: $10.18520 / \mathrm{cs} / \mathrm{v} 116 / \mathrm{i} 8 / 1363-1372$ 